\title{
(a) $\mathrm{F}$
}

ISSN 2450-6486

www.ehs-ss.pl

DOI: $10.38014 /$ ehs-ss.2020.3-1.09

\section{Наталія ДУХАНІНА, Ганна АЕСИК}

\section{Конвергентні медіа як інструмент} для пододання стресу в освітньому середовищі ЗВО упродовж тривалого карантину

NATALIIA DUKHANINA, GANNA LESYK. Converged media as a tool for overcoming stress in the Higher Education Institution during long-term quarantine. The article is devoted to the analysis of so-called new convergent media as a phenomenon of modern pedagogical culture and a tool of a modern teacher. The main possibilities of new convergent media in foreign language teaching are outlined. The students' psychological aspect has been taken into account. The authors describe the causes of stress and identify the main factors that help to mitigate stressors. The main causes of the imbalance between teachers and students in distance learning are identified. It is emphasized that media convergence is a powerful tool and technical possibilities of practical use of distance learning during quarantine.

Keywords: new media, convergent media, media space, stress, stressors, personality resistance, interactivity, convergence, media convergence, quarantine. 
Постановка проблеми. В умовах тривалого карантину та технологічних змін, які переживає людство нині, вимушеного переходу на дистанційні форми навчання, нові конвергентні медіа надають можливість налагодження зв'язку та встановлення регулярного дистанційного навчання. Проте варто зважати, що кризові ситуації, зокрема і стан карантину, сприймаються дюдиною з підвищеною інтенсивністю емоційного навантаження.

Звичні нам форми роботи в аудиторії стали немождивими, а освітній процес перенесено в електронний формат. Комунікація у звичному нам вигляді «один до всіх» втратила свою актуальність. Ії заступиди нові інтерактивні форми контактування з рівноправними відносинами викладача і студента у вищих закладах освіти, які по суті є конвергенцією навчального процесу, зокрема здиття організаційних i дидактичних заходів, спрямованих на реалізацію змісту освіти на певному освітньому або кваліфікаційному рівні відповідно до державних стандартів освіти.

Метою статті є визначення взаємовпливу тривалого карантину і конвергентних медіа на теперішнє покоління студентів, так званих міленіалів, особливості сприйняття ними загальних процесів та усвідомлення нового формату навчання, окреслення значення конвергентних медіа в умовах дистанційного навчання.

Анадіз останніх досдіджень та пубдікацій. Конвергентні нові медіа є об'єктом наукових досдіджень та суб'єктом інформаційного поля, вони у фокусі різних організацій Ради Европи, зокрема Керівного Комітету Ради Европи з питань медіа та інформаційного суспільства. Дослідженню конвергенції в медіасфері присвячено праці Дж. Д Болтера, О. Вартанова, Р. Гольфельда, Г. Дженкінса, А. Кавєріної, К. Мейєра, Д. Проценка, В. Різуна, Г. Сарміна, С. Цимбаленка, А. Юферева; проблемам медіаграмотності та розвитку критичного мислення - Г. Дженкінса, Н. Духаніної, Н. Лашук, М. Маклюена, Г. Онкович, Г. Почепцова. Питання факторів стресового стану розкрито у працях П. Гончарука, Дж. Грінберга, Г. Селье, М. Титаренка, А.Чікерінга та ін.

Виклад основного матеріалу. Упродовж останнього десятиріччя процеси мультимедіатизації та конвергенції в медійній галузі вплинули на зміни щодо отримання інформації суспільством

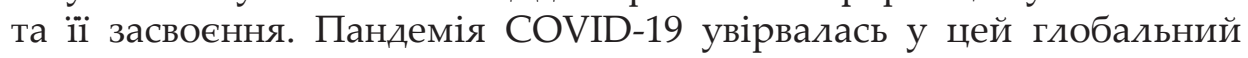
медіапростір і переповнила його тривожними повідомленнями щодо загрози життю. Такі повідомлення першочергово зачіпають 
емоційну сферу дюдини, впливають на психічний стан, сприяють входженню у стан стресу.

У роботі Дж. Грінберга «Управління стресом» виділено наступні фактори стресу для студентів першого року навчання: зміна способу життя, зміна міста або країни проживання, академічна перевантаженість, прагнення успішності в навчанні та у стосунках 3 протилежною статтю, знайомства, дружба, кохання, хвороби, міжособистісна конкуренція, насилля. До цього списку на сьогоднішній день в ситуації поширення світом пандемії, можемо ще додати булінг, небезпеку для життя, недостатність якісних консультацій спеціалістів, обмежене коло спілкування. Щоправда, добра половина із перелічених факторів актуальна загалом для студентства, а не тільки першокурсників [2].

Причинами стресу в тривалому карантині можуть бути: вплив емоційно-негативних чинників (теленовини, прогнози, навколишне середовище, фактор невизначеності, час, велика відстань з рідними, обмеження вільно пересуватися тощо), дисбаланс між вимогами та можливостями; нервово-психічні перевантаження. Усі ці чинники призводять до стресів, а в ситуації «сидьного напруження відбувається зниження пізнавальної здатності, звужується світогдяд, дюдина не здатна втримувати основні аспекти в голові протягом тривалого часу, а іiі поведінка втрачає гнучкість» [10]. На цьому зазвичай ми зупиняемося у розгляді питання стресу. Однак відмінною і цікавою нам видається думка канадського фізіодога Г. Сельє «стрес є неспецифічною відповіддю організму на будь-яку пред'явлену йому вимогу, що допомагає пристосуватися до труднощів, що виникають, впоратися 3 ними» [8]. Він перебував на позиції, що не слід боятися стресу, але навчитися ним управляти, бо він дае можливість адаптуватися до перезавантажень, мобілізувати власні мождивості, подолати страх. А також описав процес позитивного впливу стресу, який сприяє розвиткові емоційного інтелекту.

Класична концепція стресу Г. Сельє передбачає три фази (стадіі) його розвитку: 1) стадію тривоги; 2) стадію резистентності; 3) стадію виснаження. Стадія тривоги має різну протяжність, яка залежить від характеру і водьових якостей людини, і призводить до пристосування організму до нових умов існування. Стадії резистентності (адаптаціі) характеризуе період, коли організм пристосувався до нового подразника. Ця адаптація вимагає певних зусиль і затрат енергї для вироблення протистресових гормонів. Третя стадія є показником 
безвиході, відчаю, безсилля і фрустрації, які охоплюють людину у безнадійній ситуації - це стадія виснаження.

Педагоги мають втримати студентство на стадії резистентності і використати цей час як спільника у виробленні нових стратегій і розкриття спільних можливостей. Простір, зокрема і навчальний простір, вже давно видозмінюеться, але ми уперто продовжували ігнорувати цю ситуацію. Дана стресова ситуація виявила невідворотність змін в освітньому процесі, використанні нових технологій у їх масі, прискорені темпів навчання і викладачів, i студентів роботи 3 технікою, програмами, мобільними версіями курсів, опанування методиками віртуального класу, вебсервісів i гугдпродуктів тощо. Багато із перерахованого дозводяе використовувати можливості для задоволення освітніх та культурних потреб особистості, забезпечення навчального процесу ілюстративними матеріалами, інструментами для досягнення навчальної мети.

Зазначимо, що конвергентні або нові медіа нині стають головною складовою не лише досліджень та законодавчих проектів країн Европи, а насамперед інструментом для навчання в критичні часи, що обумовлені масовим довготривалим карантином. Нові медіа (англ. New Media) - інтерактивні електронні видання, що комбінують формати подання інформації; різновид цифрових медіа. Наприклад, контентом нових медіа може бути відео, онлайн-радіо, телевізійна трансляція, анімація, звукове оформлення, та, власне, текст. Від традиційних нові медіа також вирізняе користувацький контент. Нові медіа є відкритими для взаємодії з читачами та надають їм мождивість створювати та модифікувати зміст повідомлень [6; 9].

За визначенням української дослідниці $\Lambda$. Мудрак конвергентні або нові медіа $€$ «поєднанням різного виду мовлення, різного контенту:усного, писемного, аудіовізуального матеріалу. Поширення такого мовдення може відбуватися в реальному часі шляхом надання запису на замовлення. Розповсюдження відбувається через телекомунікаційні мережі з використанням нових технологій» [5].

Конвергенція (від латин. convergentis) - процес зближення, сходження (у різному сенсі), компромісів повідомлень [4]. У мовознавстві цим терміном позначають збіг у процесі фонетичних змін двох звуків у одному. У педагогіці будемо розглядати процеси конвергенціі як об'єднання різних технологій, зокрема медіатехнологій, для досягнення навчальних результатів. 
Викладачі як представники певного покоління розраховують на те, що їхні студенти будуть сприймати інформацію у відомому їм форматі, використовуватимуть методи запам'ятовування чи заучування, виконуватимуть ту ж саму послідовність дій у навчанні, якою користується і вчитель. Проте ми випускаємо з уваги той факт, що покоління, яке народжувалося з середини 90-х, так звані міленіали, сприймають інформацію як потік, подекуди мають кліпове сприйняття, не вкладають в інформацію інших змістів окрім тих, що передаються в інформативному повідомленні. Для них цілком природнім є те, що інформація доступна в будь-якому місці і в будь-який час. Вони схильні до опрацювання кількох задач одночасно, хоча це часто знижуе якість їх виконання, а подекуди й зовсім відсутня концентрація на проблемі. Для покоління міленіалів цілком природним є взаємопроникність знань і технологій; якісний контент і сервіси мають бути наявними як звичайна річ, у своїй поведінці вони підкреслюють вимогу до суспільства - поважати їх як особистість та мають гіпертрофоване прагнення визнання їхніх здобутків.

Ще однією відмінністю у користуванні інформацією міленіалів є їхне особливе ставлення до повідомлень - вони не читають тест цілком, а намагаються максимадьно його скоротити. Затримати їхню увагу на тексті допомагають картинки, а іноді й повернути до змісту викладеного. Саме ця особливість їхнього сприйняття дозволяє викладачу сконцентрувати увагу на навчальному матеріалі за допомогою конвергентних джерел. Однак слід пам'ятати, що навчальні матеріали серйозного характеру вимагають більшої концентрації, а при навчання іноземної мови ще й додаткового ресурсу - лексичного багажу, тому потрібно дозувати матеріал, підкріплювати візуальними образами, замальовувати його у вигляді ментальних карт, хмар слів тощо.

Нова технологічна епоха із різноманіттям інструментів відкрила для навчання широке поле можливостей, дозволила використання контенту різними платформами. Конвергенція як один із рушійних трансформаційних процесів в медійній сфері ставить нові вимоги до користувача, впливаєнайоговзаємодіюізмедіапростором.Зважаючи на трансформаціі у інформаційному полі, виокремлено особливості медіаконвергенціі (здиття традиційних форм медіа 3 Інтернетом; зміна мономедійного середовища на мультимедійне, діалогові відносини між учасниками інформаційної діяльності; 
трансмедійність медіаконтенту; швидкість розповсюдження; інтерактивність тощо), що впливають на ефективність інформаційнокомунікативних процесів [3, с. 373].

У освітньому процесі вже досить давно усвідомлено чи не усвідомлено педагоги використовують засоби медіа 3 навчадьною і виховною метою. Ці елементи медіаосвіти можна прослідкувати навіть в тому, коди студентам надають списки рекомендованої літератури, статті або колонки у новітніх друкованих або електронних виданнях, інформацію з блогів, підкастів, електронних енциклопедій, з джерел масових чи спеціалізованих, відеоогляди, онлайн-симулятори тощо. Така відкритість навчального простору і $є$ використанням конвергентних медіа з навчальною метою.

Вимушена ситуація зміни формату навчального процесу призвела до нагальних потреб застосування дистанційної освіти, що за способом реалізації є більше конвергентою медіаосвітою, оскільки відбувається зрощення кількох традиційних і медіа засобів навчання. В систему формальної освіти, яка нині вміщуеться у GoogleClassroom, стрімко увірвалися технологічні рішення - використання гуглдисків, гуглкалендарів, додавання матеріалів 3 YouTube, вітчизняного i зарубіжного кінематографу та мультиплікаціі; субтитровані, адаптовані і не адаптовані ролики; розміщення посилань на інтернет джерела тощо. Для мобільного навчання використовуються мобільні і портативні ІТ-пристрої, такі як смартфони, кишенькові комп'ютери, нетбуки, планшетні ПК, які забезпечують наступні мождивості: «голосовий супровід, SMS-повідомлення, графічні та відеоілюстрації, завантаження і встановлення програм, браузери мобільного Інтернету є вбудованими до цих технічних засобів і застосовують 3G або GPRSзв' язок для збільшення мережі отримуваних даних» [1, с.33].

Викладачі, створюючи заняття в гуглкласі, безпосередньо закладають послідовність комунікації автор/викладач-текст-читач/ слухач/студент та розраховують на аперцептивність суб'єктів навчальної діяльності. Їхньою метою є поліпшення знань студентів, розширення горизонтів про предметні уявленні, мовні і мовленнєві процеси, граматичні категорії тощо у новій якості й зв'язках.

Конвергентні медіа умождивлюють спілкування як конкретними категоріями так і гіпертекстуадьними масивами. Медіаосвітніми засобами в даному разі є досить широкий інструментарій - від типу прикріпленого документа, шрифтів, малюнків, ракурсів, графіків до гіпертекстових посилань. Насиченість різноплановим поданням 
матеріалу руйнуе звичку працювати за шаблоном, змушуе до активної пошукової діяльності, опрацювання інформації з різних джерел, формує навичку перевіряти і підтверджувати інформацію, зокрема долучатися до форумів і голосових порталів, чатів. Таким чином, інтерактивність створюе ефект присутності студента в медіапросторі, який знімає психологічні обмеження, зменшує стреси, викликані обмеженням життевого простору і необхідністю перебувати тривалий час в приміщенні з одними і тими ж людьми, утворює нові зв'язки, i, зрештою, орієнтує реципієнта на участь в комунікативному процесі.

Таким чином, фаза адаптації у стресовій ситуації активує здібності й удосконалюе вміння вирішувати проблеми, реально оцінювати ситуацію, пристосовуватися до нових умов, тобто дорослішати не дише студентству, а й суспільству загалом. Оскільки медіаконвергенція є процесом динамічним, інноваційним, тож i постають нові явища й нові форми навчальної діяльності. Сучасні пристрої умождивдюють доступ користувачеві до конвергентних платформ, які мають кілька функцій і пропонують різні можливості репрезентації контенту Google Classroom, BigBlueButton, Zoom, Classtime тощо.

Автори статті 3 позиції практикуючих викладачів іноземної мови (ангдійської та української як іноземної) на власному досвіді переконалися у дієвості конвергентних медіа. Так, серед найпопулярніших мобільних додатків, спрямованих на формування лексичних, граматичних та фонетичних навичок під час вивчення англійської мови можемо виділити Easy Ten, Learn English, Busuu, Memrise, Babbel, Learn English Grammar, English Grammar Practice та додатки ддя вивчення української мови іноземними громадянами «Yabluko» Elementary level», Simply Learn Ukrainian, Languagetool та інші. Зазначимо, що мобільні додатки забезпечують інтегроване навчання видів мовленневої діяльності, тобто у процесі вивчення граматики або лексики більшість додатків містять завдання 3 елементами аудіювання, письма чи говоріння. Також, мобільні додатки ефективні й для відпрацювання певних навичок, що становлять труднощі для студента.

Прикладом конвергенції у мережі (завдяки новим технологічним можливостям інтернету), що передбачае поєднання форматів текст, аудіо, графіка, світлини, анімація - є відкриті онлайн-курси Prometheus i Coursera for Campus. Вони є формою дистанційного, 
електронного навчання, зразком якісної безкоштовної освіти, що передбачає інтерактивне спілкування в режимі реального часу. Зокрема, Prometheus - громадський україномовний проект, який працюе у форматі масових відкритих онлайн-курсів й змішаного навчання, яке передбачає інтеграцію онлайн-курсів в університетську освіту. Курси містять відео-лекції найкращих викладачів провідних університетів України, інтерактивні тести, списки літератури для самостійного опрацювання та форуми для обговорення питань. Відкрита американська платформа онлайн-освіти Coursera пропонує безкоштовний доступ до понад 3800 курсів і 400 спеціалізацій, які представлені ангдійською мовою. Після успішного закінчення курсів Prometheus або Coursera студент отримує сертифікат про проходження курсу.

Загалом технологічна конвергенція охоплюе такі «технологічні перетворення, які істотно змінюють доступ до інформації і розширюють можливості ऑii трансляції та демонстрування, передусім у формі мультимедійних репрезентацій» [7]. Технологічна конвергенція диктує конвергенцію рішень, що передбачає стандартизацію інноваційних процесів, послуг, додатків і процедури доступу до мережі. По суті, така конвергенція являє собою «надання однакових послуг за допомогою різних інструментів і сукупності явищ, які постади наслідком технологічної конвергенції» [7].

Висновки та перспективи подадьших розвідок. Отже, розвиток і можливості використання нових конвергентних медіа безпосередньо залежить від технологічного еволюційного розвитку, які спричинюватимуть постійну корекцію та застосування нових дефініцій у навчальному процесі. Пандемія на даному етапі створила не лише стресові ситуації, а стала каталізатором процесів переходу до нових форм навчання. Технологічні можливості нашого часу дозволяють використання різноманітних освітніх мобільних додатків для вивчення мов, які підвищують ефективність навчання завдяки мультимедійному та інтерактивному навчальному контенту, миттевому доступу до навчальних ресурсів, структури завдань, форми спілкування та взаємодії тих, хто навчається. Освітні мобільні додатки мають чимало переваг перед традиційними методами навчання та сприяють: посиленню мотивації міленіалів до самостійного вивчення іноземної мови, подоланню комунікативного бар'єру, індивідуалізації навчання, інтерактивності, поєднанню синхронного та асинхронного навчання, швидкості передачі даних, сприйняття 
ними загадьних процесів та усвідомлення нового формату навчання. Переконані, що 3 часом нові стандарти швидкості i розвиток технологій, їхня доступність і поширеність все більше заповнюватимуть навчальний процес, а виникнення і поширення мобільних додатків розширюватиме навчальні горизонти за рахунок даного контенту.

\section{References:}

1. Горбатюк Р.М. Мобільне навчання як нова технологія вищої освіти. Науковий вісник Ужгородського університету: Серія: Педагогіка. Соціальна робота / гол. ред. І.В. Козубовська. 2013. Вип. 27. С. 31-34.

2. Гринберг Дж. Управление стрессом. СПб. : Питер, 2002. 496 с.

3. Духаніна Н.М. Ефективність інформаційно-комунікативних процесів у сучасному медійному просторі. Молодий вчений. 2020. № 3 (79). С. 489-492.

4. Конвергенція. URL: https://uk.wikipedia.org/wiki/\%D0\%9A\%D0\%BE\%D0\%BD \%D0\%B2\%D0\%B5\%D1\%80\%D0\%B3\%D0\%B5\%D0\%BD\%D1\%86\%D1\%96\%D1\% 8F (дата звернення: 10.04.2020).

5. Мудрак Л. Конвергентні медіа як наукова категорія та суб'єкт інформаційного простору. URL: http://visnyk.academy.gov.ua/wp-content/ uploads/2013/11/2013-2-34.pdf (дата звернення: 10.04.2020).

6. Нові медіа. URL: https://uk.wikipedia.org/wiki/\%D0\%9D\%D0\%BE\%D0\%B 2\%D1\%96_\%D0\%BC\%D0\%B5\%D0\%B4\%D1\%96\%D0\%B0 (дата звернення: 14.04.2020).

7. Сармина А.Д. Медиаконвергенция как фактор формирования кросс-медиа. URL: file://C:/Users/Ganna/Downloads/Nzizh_2017_1_15.pdf (дата звернення: 14.04.2020).

8. Селье Г. Стресс без дистресса. Рига : ВИЕДА, 1992. 109 с. URL: https:// www.rulit.me/books/stress-bez-distressa-read-15443-1.html (дата звернення: 14.04.2020).

9. Crosbie, V. What is New Media? 2002. URL: http://rebuildingmedia.corante. com/archives/2006/04/27/what_is_new_media.php (дата звернення: 11.04.2020).

10. Holsti Ole R. Crisis Decision making. Diplomacy: New Approaches in History, Theory and Policy / Ed. Paul G. Lauren. New-York : Free Press, 1979.

\section{Transliteration of References:}

1. Horbatiuk, R.M. (2013). Mobilne navchannia yak nova tekhnolohiia vyshchoi osvity. Naukovyi visnyk Uzhhorodskoho universytetu: Seriia: Pedahohika. Sotsialna robota / hol. red. I.V. Kozubovska, vol. 27, pp. 31-34. (in Ukrainian)

2. Grinberg, Dzh. (2002). Upravlinnia stresom. Saint-Petersburg: Piter (in Russian)

3. Dukhanina, N.M. (2020). Efektyvnist informatsiino-komunikatyvnykh protsesiv u suchasnomu mediinomu prostori. Molodyi vchenyi, № 3 (79), pp. 489-492. (in 
Ukrainian)

4. Konverhentsiia. Available at: https://uk.wikipedia.org/wiki/\%D0\%9A\%D0\%BE \%D0\%BD\%D0\%B2\%D0\%B5\%D1\%80\%D0\%B3\%D0\%B5\%D0\%BD\%D1\%86\%D1 $\% 96 \%$ D1\%8F (accessed 10 April 2020). (in Ukrainian)

5. Mudrak, L. Konverhentni media yak naukova katehoriia ta subiekt informatsiinoho prostoru. Available at: http://visnyk.academy.gov.ua/wpcontent/uploads/2013/11/2013-2-34.pdf (accessed 10 April 2020). (in Ukrainian)

6. Novi media. Available at: https:/uk.wikipedia.org/wiki/\%D0\%9D\%D0\%BE\%D0 \%B2\%D1\%96_\%D0\%BC\%D0\%B5\%D0\%B4\%D1\%96\%D0\%B0 (accessed 14 April 2020). (in Ukrainian)

7. Sarmina, A.L. Medyakonverhentsyia kak faktor formyrovanyia kross-medya. Available at: file://C:/Users/Ganna/Downloads/Nzizh_2017_1_15.pdf (accessed 14 April 2020). (in Russian)

8. Sel`e, H. (1992). Stress bez dystressa. Ryha : VYEDA, 109 p. Available at: https:// www.rulit.me/books/stress-bez-distressa-read-15443-1.html (accessed 14 April 2020). (in Russian)

9. Crosbie, V. (2002). What is New Media? Available at: http://rebuildingmedia. corante.com/archives/2006/04/27/what_is_new_media.php (accessed 11 April 2020).

10. Holsti Ole R. (1979). Crisis Decision making. Diplomacy: New Approaches in History, Theory and Policy / Ed. Paul G. Lauren. New-York : Free Press.

\section{Authors}

Nataliia Dukhanina

National Technical University of Ukraine

"Kyiv Polytechnic Institute named after Igor Sikorsky",

Kyiv, Ukraine

E-mail:voytkonm@gmail.com

Ganna Lesyk

National Aviation University,

Kyiv, Ukraine

E-mail: lesykganna@gmail.com

Abstracts

НАТАЛІЯ ДУХАНІНА, ГАННА ЛЕСИК. Конвергентні медіа як інструмент для подолання стресу в освітньому середовищі ЗВО упродовж тривалого карантину. У статті розглядаються та аналізуються так звані нові конвергентні медіа за умов 
змін медіапростору та еволюиійних технологічних змін як інструмент сучасного педагога та як феномен новітньої педагогічної культури. Окреслено головні можливості інструментарію для навчання іноземної мови через запозичення з практики мас-медіа. Акцентовано на причннах стресу, визначенні основних чинників та факторів, щзо можуть пом'якщити негативні чинники стресу. Наголошено на медіаконвергентності як інструменті сучасної освіти. Виявлені основні причини дисбалансу між викладачем та студентом в процесі дистанційного навчання. Установлено, що медіаконвергенція $\epsilon$ потужним інструментом і технічними можливостями практичного застосування дистанційної форми навчання в умовах тривало20 карантину.

Ключові слова: нові медіа, конвергентні медіа, медіапростір, стрес, стрес-фактори, резистентність особистості, інтерактивність, конвергенція, медіаконвергенція, тривалий карантин.

\section{НАТАЯИЯ ДУХАНИНА, АННА ЯЕСИК. Конвергентные ме- диа как инструмент для преододения стресса в образова- тельной среде УВО на протяжении ддительного каранти-}

на. В статье рассматриваются и анализируются так называемые новые конвергентные медиа в условиях изменений медиапространства и әволюичинных технологических изменений как инструмент современного педагога и как феномен новейшей педагогической культуры. Определены главные возможности инструлентария для обучения иностранному языку через заимствования из практики масс-медиа. Акцентировано на причинах стресса, определении основных факторов, которые могут смягчить негативные факторы стресса. Сделано ударение на медиаконвергентности как инструменте современного образования. Определены основные причины дисбаланса между преподавателем и студентом в процессе дистанизионного обучения. Установлено, что медиаконвергенция является мощным инструментом и техническими возможностями практического применения дистанционной формы обучения в условиях длительного карантина.

Ключевые слова: новые медиа, конвергентные медиа, медиапространство, стресс, стресс-факторы, резистентность личности, интерактивность, конвергенция, медиаконвергенция, длительный карантин. 
NATALIA DUCHANINA, HANNA ŁESYK. Media konwergentne jako narzędzie przezwyciężania stresu $\mathrm{w}$ środowisku uczelni wyższych podczas długoterminowej kwarantanny. Artykut rozważa $i$ analizuje $t z w$. nowe media konwergentne $w$ warunkach zmian $w$ przestrzenimedialnejiewolucyjnych zmian technologicznych jakonarzędzie nowoczesnego pedagoga i zjawisko wspótczesnej kultury pedagogicznej. Przedstawiono główne możliwości narzędzi do nauki języka obcego poprzez zapożyczanie z praktyki środków masowego przekazu. Nacisk kładziony jest na przyczyny stresu, identyfikacje głównych czynników i czynników, które moga złagodzić negatywne stresory. Nacisk kładziony jest na konwergencje mediów jako narzędzie nowoczesnej edukacji. Zidentyfikowano główne przyczyny braku równowagi między nauczycielem a studentem $w$ procesie zdalnego uczenia się. Ustalono, że konwergencja mediów jest potężnym narzędziem $i$ technicznymi możlizwościami praktycznego zastosowania nauczania zdalnego w warunkach dtugoterminowej kwarantanny.

Słowa kluczowe: nowe media, media konwergentne, przestrzeń medialna, stres, czynniki stresowe, odporność osobowości, interaktywność, konwergencja, konwergencja mediów, długoterminowa kwarantanna. 